\title{
INTERNATIONAL COMPETITIVENESS AND RESTRUCTURING OF THE CROATIAN FOOD INDUSTRY
}

\author{
Goran BUTURAC - Željko LOVRINČEVIĆ - Davor MIKULIĆ
}

(Received: 21 January 2016; revision received: 16 May 2016; accepted 30 May 2016)

\begin{abstract}
The goal of this article is to provide a deeper insight to the overall contribution of the export of food products to the Croatian economy and to estimate the direct and indirect impact of the international competitiveness of food producers on other domestic sectors. The authors measure the importance of the food sector by employing both the constant market share (CMS) and the input-output analysis. The results indicate that a loss in competitiveness in the Croatian food industry was the most important factor that determined the decreasing share of national companies in the period from 2009, when the global recession started, up to 2013, when Croatia joined the EU. EU membership strongly and positively influenced the performance of Croatian food exports. The negative trend regarding the share of the international food market was reversed. Besides having a direct impact on the export performance of the food industry, the international competitiveness of food producers indirectly affects other domestic companies whose products are used as intermediate inputs in the food industry. The study also presents a benchmark of results with previous research for EU countries, which rarely included Croatia before the accession in 2013. As far as output and value added are concerned, multipliers for the food industry are relatively significant and higher than the national average, and the food industry could be assessed as one of the key Croatian economic sectors.
\end{abstract}

Key words: Croatian food industry, competitiveness, industry multipliers based on input-output model, European Union

JEL classification indices: C67, F40

Goran Buturac, corresponding author. Senior research fellow at the Institute of Economics, Zagreb, Croatia. E-mail: gbuturac@eizg.hr

Željko Lovrinčević, Senior research fellow at the Institute of Economics, Zagreb, Croatia. E-mail: zlovrincevic@eizg.hr

Davor Mikulić, Senior research fellow at the Institute of Economics, Zagreb, Croatia.

E-mail: dmikulic@eizg.hr 


\section{INTRODUCTION}

\subsection{Goals and motivation of the research}

In the case of small economies with limited domestic markets, the export orientation of domestic companies is extremely important for the optimisation of the production process. The international competitiveness of the food industry has been broadly analysed in recent literature, especially for the set of new European Union (EU) economies in which agriculture and related food industries represent a significant part of the overall economy. The short review of the methods applied and the main results of previous studies are presented in the next section.

The food industry is the most significant sector of the Croatian manufacturing industry and it indirectly affects other domestic sectors included in the value added chain of the food industry. In economic literature, the input-output model is the most widely used method, which is able to quantify not only the direct, but also the indirect effects and the total impact of certain economic sectors to the domestic gross value added (GVA) and employment. The Croatian Statistical Office recently published an input-output table, which enabled researchers to estimate the total impact of certain sectors according to the methodology established by Leontief (1986) and developed by Miller - Blair (2009). The paper attempts to fill the gap in empirical research based on input-output analyses, which have been neglected in Croatia. It tries to provide empirical evidence on the sources of international competitiveness and therefore to enable a comparison with other EU countries because Croatia was rarely included in the previous studies on EU and the new member states (NMSs). The decline in competitiveness of the overall processing industry of Croatia has been demonstrated by Buturac (2013). The international competitiveness of some Croatian labour-intensive industries has been examined for the wood (Lovrinčević et al. 2015) and textile industry (Buturac et al. 2014).

The hypothesis of the paper is that the Croatian food industry was continuously decreasing its share on the global and EU market as a consequence of weak international competitiveness, which contributed to the prolongation of the economic recession in the overall value added chain of the food industry. However, EU membership in 2013 changed the course of events and reversed the trend in the food industry. The study employs two complementary methods. While the constant market share (CMS) identifies the factor that explains trends in exporting products from the food industry, the input-output method goes one step further and quantifies the impact of exports on other domestic sectors. The geographical and product structure as well as the international competitiveness of food producers affect not only the food industry, but also the economic activity of all 


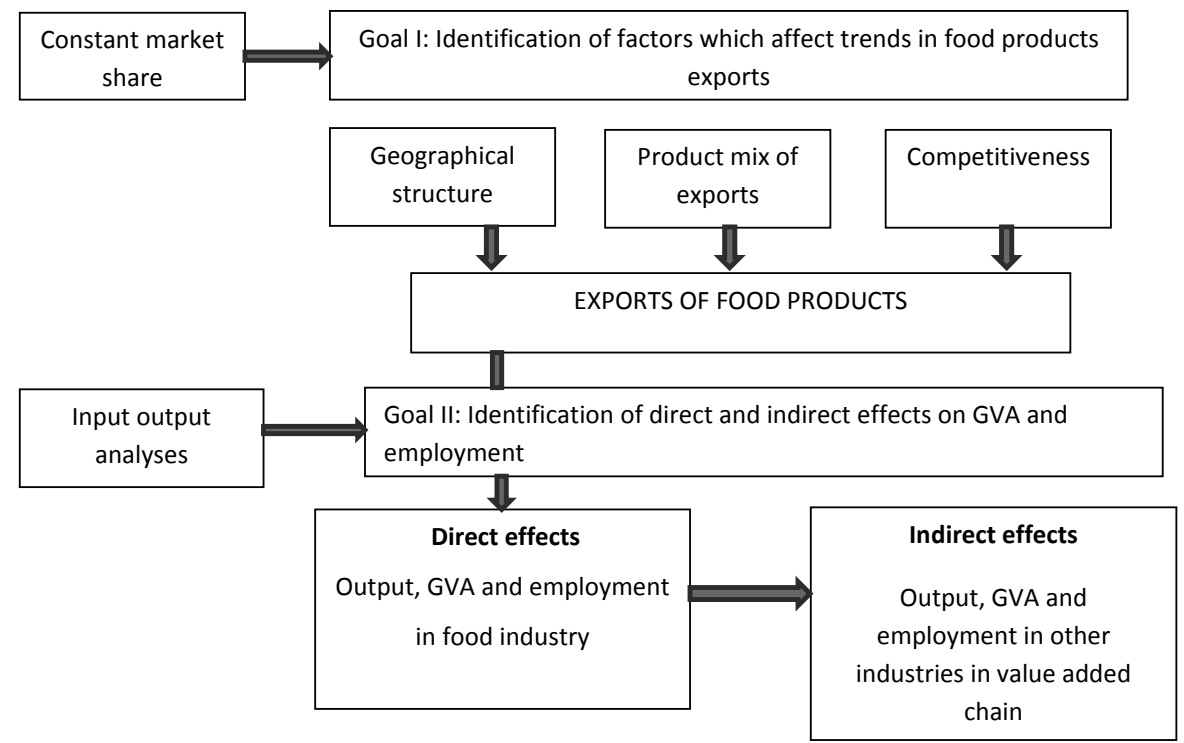

Figure 1. Research goals and methodology applied

units included in the value added chain of the food industry. The role of the two alternative methods is presented in Figure 1.

\subsection{A short literature review}

In recent literature, factors behind the trends in food industry exports were the subject of numerous studies, especially for the group of NMSs of the EU which joined in 2004 and 2008, countries where the food industry was one of the most important economic sectors. Authors often conducted a comparative study on a sample that included the group of NMSs or the entire EU. As a country outside the EU until 2013, Croatia was usually not included in those surveys.

In a recent article, Bojnec - Fertó (2015) empirically tested the competitiveness of the agri-food exports of EU countries using a broad range of different methods: panel unit root tests, a mobility index, and the Kaplan-Meier survival rates of the $B$ index ${ }^{1}$ as a measure of changes in revealed comparative advantage. The EU-27 countries have been competitive in agri-food exports, with the B in-

$\mathrm{B}$ index as a measure of Revealed Comparative Advantage has been defined by Balassa (1965) as follows: $\mathrm{B}=\left(\mathrm{x}_{\mathrm{ij}} / \mathrm{x}_{\mathrm{ig}}\right) /\left(\mathrm{x}_{\mathrm{wj}} / \mathrm{x}_{\mathrm{wg}}\right)$, where $\mathrm{x}$ stands for exports, $i$ denotes a country, $j$ is a commodity, $g$ is a set of commodities and $w$ represents a set of countries that are used as the benchmark 
dices for the EU-12 countries (NMSs) being higher than for the EU-15 countries (old EU members). The comparative advantage is improving in EU-15 countries, while stagnation or deterioration is seen in the EU-12. As for the duration of the advantages, researchers detected higher numbers of agri-food products with a longer duration of export competitiveness for EU-15 than for EU-12. Carraresi Banterle (2015) also assessed the competitiveness of the European food industry based on the export market share method (EMS) and the revealed comparative advantages method (RCA). The EMS method assesses the export orientation of a country for a specific sector compared to a set of countries, while the RCA method measures the country export specialisation of a specific sector. The authors found significant differences among EU countries. While an increase of competitiveness is found in Germany and Austria, France, Belgium, Denmark, and Greece are lagging behind. The foreign trade of food products in most NMS (Török - Jámbor 2013) has become more intensive after the accession. In spite of the growth of export, these surveys often found a serious deterioration in the NMS agri-food trade balance. The accession has radically changed the survival time of agri-food trade companies.

Bojnec - Fertő (2010a) analysed agro-food trade structures in a group of Central and Eastern European countries (CEECs) with the European Union (EU-15) market in order to identify the trends in specialisation during the pre-accession period. They found a convergence of agro-food trade specialisation for CEECs and an existence of convergences towards greater structural similarity with the EU-15 market. The authors concluded that some of the CEECs in the pre-accession period faced substantial obstacles. Adjustments and structural changes of CEECs' agro-food export were needed in order to increase competitiveness on the EU-15 market. Also, Bojnec - Fertő (2009) explored the level, composition, and differences in agro-food relative trade advantages for eight Central European and Balkanic countries on the EU markets and their implications for food policy. They found higher and more stable relative trade advantages for bulk primary raw agricultural commodities and less for consumer-ready foods, implying competitiveness shortcomings in food processing and in international food marketing.

In contrast to studies where Croatia was not included in the sample, there were also studies which covered the Croatian food industry, although usually in a sample which was not related to the group of NMSs or EU countries. International competitiveness in the agri-food industry in countries situated in the Danube region on the basis of the standard Balassa (RCA-revealed comparative advantage) index and trade performance indexes was presented by Ignjatijević et al. (2015).

for comparison. If $\mathrm{B}>1$, a country has revealed comparative advantage in the export of $j$ commodity on the world market. The opposite holds if $\mathrm{B}<1$. 
They found that the competitiveness of the Croatian food industry reduced and there is a strong correlation of the RCA index for other economies. Bojnec - Ferto (2010b) analysed the agri-food trade specialisation patterns of South-Eastern European (SEE-6) countries with the EU-15 in the period 1995-2007 by main food products groups classified by the degree of product processing and trends on EU-15 markets. The authors concluded that the SEE countries besides Serbia and Montenegro experienced an increasing trade deficit in agri-food products with the EU-15. The export of food products in the sampled countries was assessed as highly concentrated in bulk raw commodities with a lack of export specialisation for higher-valued processed food products, but export specialisation in SEE was improving toward the most dynamic demand growth products on the EU-15 markets, except for Croatia and Bosnia and Herzegovina.

Bojnec - Fertő (2007) also used the Balassa index to assess the level of competitiveness of the food industry in Hungary, Croatia, and Slovenia in order to empirically test how revealed comparative advantages have developed across countries on the level of product groups in different periods. The authors concluded that the most important comparative advantage in the food industry had been attained by Hungary and Croatia, while Slovenia lagged behind. The difference in results on the position of the Croatian food industry can be attributed to the time period included in the research. While Ignjatijević et al. (2015) analysed the most recent period, the comparative research on the three countries (BojnecFertö 2007) is based on a period prior to the global recession, which seriously affected the Croatian economy.

Besides the literature dealing with the group of countries, there were also many national surveys on competitiveness in the food industry. Majkovič et al. (2007) investigated the Slovenian food industry, Vološin et al. (2011), Belova et al. (2012), and Prochazka - Smutka (2012) presented the situation in the Czech Republic. They concluded that the Czech agrarian trade did not reflect a comparative advantage in the EU or on the world market, and only individual segments of Czech food product trade were able to explore comparative advantage in relation to individual countries, Rusali (2013) concentrated on the Romanian food industry in order to investigate the comparative advantages of agri-food products in the period before and after EU membership. Based on the degree of trade specialisation, the contribution of each product is evaluated regarding the level of specialisation on international markets. Except for cereals and tobacco, a downward trend in the specialisation level is found for most products in the post-accession period. Qineti et al. (2009) studied Slovakian competitiveness and described the pattern of agri-food trade in Slovakia and the EU using the Balassa index. They concluded that the extent of trade specialisation exhibited a declining 
trend and Slovakia lost a comparative advantage for a number of product groups over time, although different tendencies for different markets were found.

Balla (2014) identified the key economic sectors for Romania, Slovakia, and Hungary based on input-output tables disaggregated to 13 sectors. The food industry is grouped together in the food, beverages, and tobacco sector, and the multiplier which presents output backward linkages for this sector is estimated in the range between 1.77 for Slovakia and 2.08 for Hungary. The food industry is assessed as the key economic sector in Hungary, while its importance in Slovakia and Romania is also significant, but there are other sectors with a dominant role regarding indirect effects on the national economy (trade in Romania and electricity, gas, and water in Slovakia).

Šidlauskaite - Miškinis (2013) used the input-output model in an analysis of the production and trade structure in the Baltic countries. They analysed the backward and forward inter-industry linkages of the manufacturing and service industries and found that the share of sectors creating a lower value added had decreased and that a deeper economic integration could be observed in the majority of the industrial sectors of the Baltic countries. They estimated that backward linkages for the food industry for internal interdependence in 2009 was above average and ranged between $73 \%$ for Lithuania and $96.8 \%$ in Latvia. This percentage of output growth was indirectly induced by the increase of demand for products from a certain sector.

\section{METHODOLOGY AND DATA SOURCES}

\subsection{Trends in food industry exports}

In 2014 , the food industry in Croatia employed 55.7 thousand people $(21 \%$ of the total manufacturing industry) and created a gross value added of HRK 6.7 billion (19\% of the manufacturing industry). The other important manufacturing industries in Croatia are production of metal products, except machinery and equipment (14\% of GVA), production of other non-metallic mineral products ( $7 \%$ of GVA in the manufacturing industry), and the production of basic pharmaceutical products and pharmaceutical preparations ( $6 \%$ of GVA). The four most significant industries create almost one-half of the total GVA in the manufacturing industry.

The Croatian food industry has recently increased its degree of integration on the international market. In the period 2001-2015, the export orientation of the food industry, measured as the share of exports of the food industry in nominal 


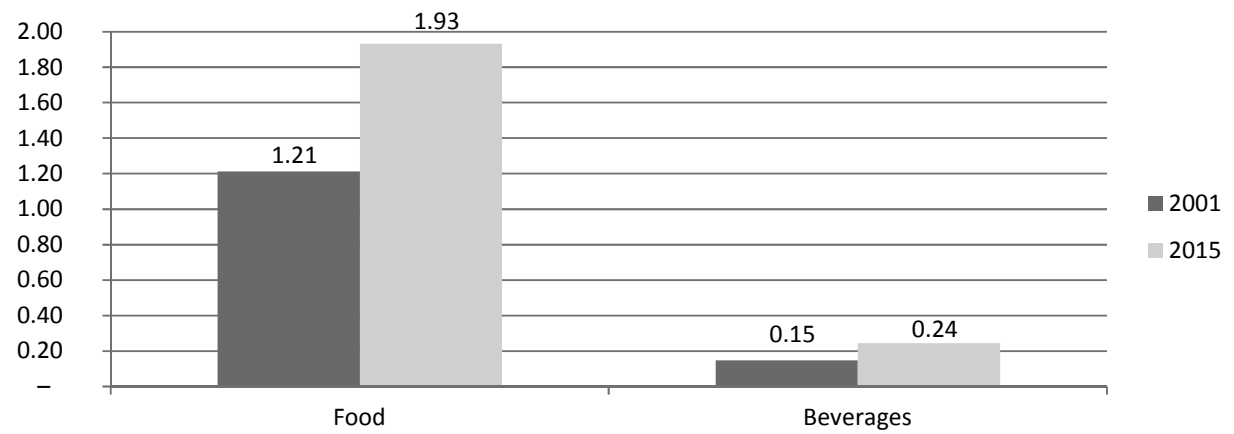

Figure 2. The export shares of the Croatian food industry in nominal GDP in 2001 and 2015 (\%)

Source: Authors' calculations based on data from the UN COMTRADE Database.

GDP, increased from $1.21 \%$ to $1.93 \%$ (Figure 2). Export shares for beverages increased even more rapidly.

Croatian exports of food products have recently passed through different phases (Figure 3). Strong export growth was recorded in the period prior to the global recession (2008-2009). Favourable trends on international markets coupled with a higher degree of openness and the international integration of the Croatian economy positively affected food industry exports, which recorded continuous growth until 2008. Vegeta, Gavrilović, Kraš, etc., are Croatian products that have been

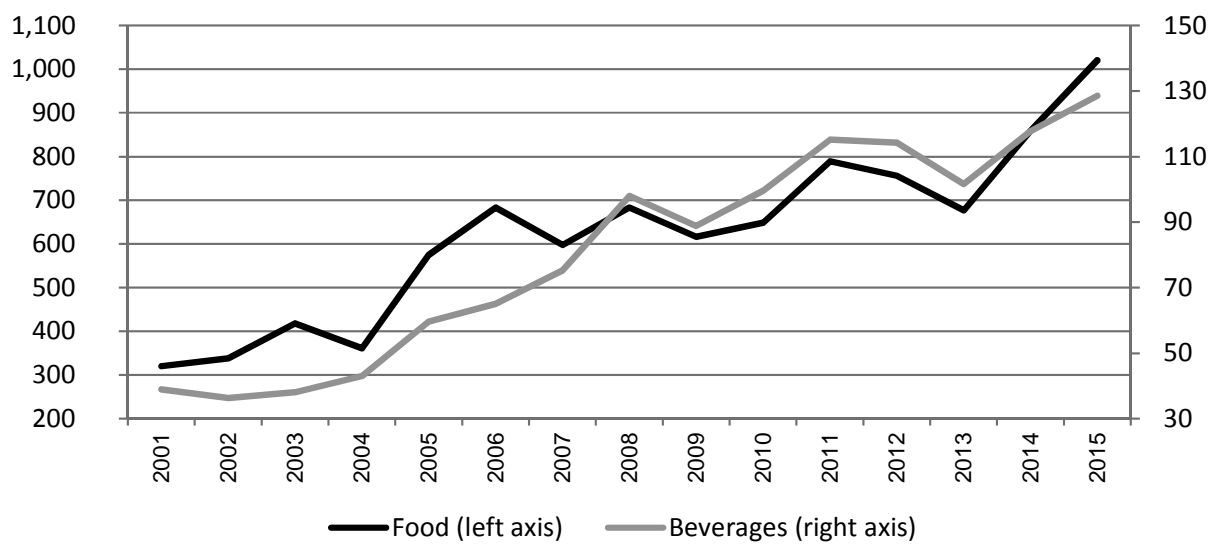

Figure 3. Export of the Croatian food industry to the world market in the period 2001-2015 (current million euros) 
well known on international markets for decades. After the decrease of exports in 2009, a consequence of the drop in foreign demand, the food industry recovered in 2010 and reached exports even higher than recorded in the pre-recession period. The relatively weak domestic demand and highly competitive market are factors which contributed to the reorientation of Croatian food producers to international markets. Also, the EU accession brought new challenges to Croatian food producers as well as the reconstruction of production mix and technology, which was needed in order to regain competitiveness on the EU market.

\subsection{Constant market share methodology (CMS)}

The CMS analysis is applied to quantify export performance and sources of international competitiveness of the Croatian food industry. Various factors have been identified behind the decreasing share of exports in the total world trade in the economic literature:

(a) national exports in food products may be concentrated on products that are experiencing a lack of demand;

(b) the concentration of exports of food products to relatively stagnant regions;

(c) weak international competitiveness of the domestic food industry.

The CMS method was first applied in research conducted by Tyszynski (1951). The methodological and empirical improvements of the CMS technique are proposed by numerous authors who all used a similar concept (Baldwin 1958; Leamer - Stern 1970; Richardson 1971; Jempa 1986; Fagerberg - Sollie 1987; Merkies - van der Meer 1988; Milana 1988; Kapur 1991).

According to the revised version of the constant market share (Milana 1988), trends in total exports can be decomposed into four components:

where

$$
\mathrm{TE}=\mathrm{CE}+\mathrm{PE}+\mathrm{GE}+\mathrm{RE}
$$

$\mathrm{TE}=$ total effect,

$\mathrm{CE}=$ competitiveness effect,

$\mathrm{PE}=$ product effect,

$\mathrm{GE}=$ geographical effect,

$\mathrm{RE}=$ residual effect. 
The total effect is calculated as follows:

$$
\mathrm{TE}=\left[\frac{\sum_{m} \sum_{p} q_{m, p}^{t}}{\sum_{m} \sum_{p} Q_{m, p}^{t}}-\frac{\sum_{m} \sum_{p} q_{m, p}^{t-1}}{\sum_{m} \sum_{p} Q_{m, p}^{t-1}}\right] \times 100
$$

The competitiveness effect:

$$
\mathrm{CE}=\sum_{m} \sum_{p} 0.5 \times\left[\frac{q_{m, p}^{t}}{Q_{m, p}^{t}}-\frac{q_{m, p}^{t-1}}{Q_{m, p}^{t-1}}\right] \times\left[\frac{Q_{m, p}^{t-1}}{\sum_{m} \sum_{p} Q_{m, p}^{t-1}}+\frac{Q_{m, p}^{t}}{\sum_{m} \sum_{p} Q_{m, p}^{t}}\right] \times 100
$$

The product effect:

$$
\mathrm{PE}=\sum_{m} \sum_{p} 0.5 \times\left[\frac{q_{m, p}^{t-1}}{Q_{m, p}^{t-1}}+\frac{q_{m, p}^{t}}{Q_{m, p}^{t}}\right] \times\left[\frac{\sum_{m} Q_{m, p}^{t-1}}{\sum_{m} \sum_{p} Q_{m, p}^{t}}-\frac{\sum_{m} Q_{m, p}^{t}}{\sum_{m} \sum_{p} Q_{m, p}^{t-1}}\right] \times 100
$$

The geographical effect:

$$
\mathrm{GE}=\sum_{m} \sum_{p} 0.5 \times\left[\frac{q_{m, p}^{t-1}}{Q_{m, p}^{t-1}}+\frac{q_{m, p}^{t}}{Q_{m, p}^{t}}\right] \times\left[\frac{\sum_{p} Q_{m, p}^{t}}{\sum_{m} \sum_{p} Q_{m, p}^{t}}-\frac{\sum_{p} Q_{m, p}^{t-1}}{\sum_{m} \sum_{p} Q_{m, p}^{t-1}}\right] \times 100
$$

The residual effect equals the difference between the total effect and individual components:

$$
\mathrm{RE}=\mathrm{TE}-(\mathrm{CE}+\mathrm{PE}+\mathrm{GE})
$$

where

$q^{t}=$ aggregate exports of an industry,

$q_{p}^{t}=$ exports of the $\mathrm{p}$-th commodity of an industry,

$Q_{p}^{t}=$ world exports of the $\mathrm{p}$-th commodity,

$m=$ market index,

$p=$ product index

$t=$ time.

An explanation of the aforementioned effects on the industry's export growth from the basic model is displayed in Table 1. 
Table 1. Description of effects in the CMS model

\begin{tabular}{l|l}
\hline \multicolumn{1}{c|}{ Effect } & \multicolumn{1}{c}{ Description of meaning } \\
\hline Total effect (TE) & $\begin{array}{l}\text { The total effect measures the annual change of a certain industry's } \\
\text { aggregate export share in world trade. A positive value suggests } \\
\text { that the exports of a certain industry expanded faster compared } \\
\text { to the rest of the world, while a negative value indicates the op- } \\
\text { posite. }\end{array}$ \\
\hline Competitiveness effect (CE) & $\begin{array}{l}\text { The competitiveness effect reveals the capacity of a certain indus- } \\
\text { try to increase its market share due to competitiveness factors only, } \\
\text { independent of structural developments in markets or in a product } \\
\text { trade pattern. A positive value indicates a competitive advantage of } \\
\text { the exports of a certain industry compared to the rest of the world, } \\
\text { while a negative value indicates a disadvantage. }\end{array}$ \\
\hline Product effect (PE) & $\begin{array}{l}\text { The product effect is part of export growth attributed to the compo- } \\
\text { sition of a certain industry's export by commodities. The product } \\
\text { effect is positive if export is concentrated in commodities in which } \\
\text { world demand is growing rapidly. }\end{array}$ \\
\hline Geographical effect (GE) & $\begin{array}{l}\text { The geographical effect measures the effect related to the geo- } \\
\text { graphical breakdown of exports. This effect is positive if the in- } \\
\text { dustry's export is concentrated in markets which have been ex- } \\
\text { periencing rapid growth. A negative value shows that the exports } \\
\text { of a certain industry are directed to markets in which demand is } \\
\text { growing slower than in international trade. }\end{array}$ \\
\hline Residual effect (RE) & $\begin{array}{l}\text { Residual effect captures the difference between the actual export } \\
\text { growth and the growth that would have occurred if the export } \\
\text { shares remained constant. }\end{array}$ \\
\hline
\end{tabular}

Source: Authors' compilation according to Milana (1988).

The constant market share model was used to explore the export performance of the Croatian food industry in the global market as well as in EU-15 and EU-27 markets from 2001 to 2015. The analysis of changes in export shares was based on three sub-periods, 2001-2005, 2006-2010, and 2011-2015. The use of the three sub-periods makes the analysis more plausible and avoids issues related to business cycles. The empirical work was focused on 16 major products. The export data set was obtained from the UN Comtrade database. ${ }^{2}$ The data set was disaggregated at the two $\mathrm{HTS}^{3}$ code level. Data values are expressed in current million euros.

The CMS method presents a convenient analytical framework, but the application and interpretation of the method has some limitations that must be taken into

2 The UN Comtrade database was used for the export data because of data availability and international comparability in the period 2001-2015. Other sources of data such as the Croatian National Bureau for Statistics offers data at the 2- and 4-digit HTS code level only for the period 2012-2015, which is not appropriate for the purpose of this analysis.

3 HTS is the abbreviation for Harmonized Tariff System. 
account (Ahmadi - Esfahani 2006). The most significant limitation is that the CMS is applied to a discrete time period. Milana (1988) proposes a satisfactory solution for this limitation, by applying the decomposition to discrete observations at the beginning and the end of the period. The Milana-model (1988) has been extended using dynamic development, with the decomposition method applied to each observation of the time horizon, and the results of the CMS analysis are time series. The interpretation of the residual effect is not as straightforward as the interpretation of competitiveness, the product, or the geographical effect. A negative residual implies a failure in maintaining constant market shares and according to the basic assumption ${ }^{4}$ of the CMS analysis, this residual is related to changes in relative prices. However, the basic assumption ignores the impact of numerous other factors that affect the stability of the country's exports, the most important of these being differences in quality, development of new exports, and improvements in the efficiency of marketing or in the terms of financing export activities. In spite of these limitations and constraints, the dynamic consideration of the CMS analysis in general successfully identifies changes in the trade structure and competitiveness over time.

\subsection{Concept of multipliers in the input-output model}

The official I/O tables for the Croatian economy cover data for 2004 and 2010. $\mathrm{I} / \mathrm{O}$ tables are usually published with a considerable delay, but because of limited technology changes in the short run, this approach could give a useful insight into the importance of the food industry. The term food industry comprises the production of food and beverages and covers section 15 of the Classification of Products by Activities (CPA) 2002 in 2004 and sections 10 and 11 of the CPA 2007 classification in 2010.

The input-output analysis is based on a static presentation of the structural relationship among different industries in the national economy. An analytical ap-

4 The basic assumption of the CMS approach is that a country's export share in world markets should remain unchanged over time. The theoretical foundations of this assumption are drawn from the idea that demand for exports in a given market from competing sources is a function of relative prices. This suggests that export shares will remain constant, except when relative prices vary. This establishes the validity of the constant share norm and suggests that the difference between the export growth implied by the constant-share norm and the actual export growth may be attributed to price changes. The discrepancy between the constant-share norm and actual performance has been labelled the competitiveness effect. Thus when a country fails to maintain its share in world markets, the competitiveness term will be negative and will indicate price increases for the country in question somewhat greater than its competitors. 
proach is generally oriented to the estimation of the impact that the final demand has on domestic output, gross value added, employment, and prices. The concept of an inter-sectoral relationship between economic units is very old, but usually Wassily Leontief is considered the main developer of the I/O analysis (Ten Raa 2005; Miller - Blair 2009).

In the I/O framework, matrix A usually presents a technical coefficient matrix (ratios of the inputs of each industry in the gross output), $\mathrm{x}$ is a vector of gross output, and y a vector of final demand. The model could be specified in terms of total technical coefficients (domestic and imported intermediates) or in the terms of domestic technical coefficients, which describe only part of the value added chain related to deliveries between domestic producers. As Eurostat recommends official tables to be published separately for the domestic and imported components of technical coefficients, this type of model is used in the research.

The total economy in the input-output mode is decomposed into $n$ sectors. According to Eurostat recommendations, the input-output tables are to be published for 64 sectors, which are based on the classification of products by activities (CPA 2008) $)^{5}$. The Croatian I/O table for 2010 is available on the same level of aggregation.

In the context of the input-output model, each sector delivers products to other producers, which use it as intermediate consumption, or to units that are final consumers (households, governments, and non-residents). The total supply of each product can be decomposed according to the following $\mathrm{n}$ equations:

$$
\mathrm{x}_{1}=\mathrm{a}_{11}{ }^{\mathrm{D}} \mathrm{x}_{1}+\ldots+\mathrm{a}_{1 \mathrm{j}}{ }^{\mathrm{D}} \mathrm{x}_{\mathrm{j}}+\ldots \mathrm{a}_{1 \mathrm{n}}{ }^{\mathrm{D}} \mathrm{x}_{\mathrm{n}}+\mathrm{f}^{\mathrm{D}} 1
$$

$$
x_{i}=a_{i 1}{ }^{D} x_{1}+\ldots+a_{i j}{ }^{D} x_{2}+\ldots a_{i n}{ }^{D} x_{3}+f^{D} i
$$

$$
\mathrm{x}_{\mathrm{n}}=\mathrm{a}_{\mathrm{n} 1}{ }^{\mathrm{D}} \mathrm{x}_{1}+\ldots+\mathrm{a}_{\mathrm{nj}}{ }^{\mathrm{D}} \mathrm{x}_{\mathrm{j}}+\ldots \mathrm{a}_{\mathrm{nn}}{ }^{\mathrm{D}} \mathrm{x}_{\mathrm{n}}+\mathrm{f}^{\mathrm{D}} \mathrm{n} .
$$

The total value of deliveries of each sector $\left(\mathrm{x}_{\mathrm{i}}\right)$ can be decomposed into deliveries that other sectors used as intermediate consumption $\left(\mathrm{a}_{\mathrm{ij}}{ }^{\mathrm{D}} \mathrm{x}_{\mathrm{j}}\right)$ and deliveries for the final consumption that includes exports. Input-output coefficients for domestic products are denoted by $\mathrm{a}_{\mathrm{ij}}{ }^{\mathrm{D}}$ and stand for the share of products delivered by sector $i$ to sector $j$ in order to be used as the intermediate consumption of sector $j$ in the total value of production of sector $j$. A central assumption of the inputoutput model is that technical coefficients $\left(\mathrm{a}_{\mathrm{ij}}\right)$ are fixed and each sector needs inputs from other sectors in order to produce a certain value of products, which

$5 \quad$ http://ec.europa.eu/eurostat/web/cpa-2008. 
are determined by $\mathrm{a}_{\mathrm{ij}}$. Each sector therefore delivers products to other sectors in the amount defined by $\mathrm{a}_{\mathrm{ij}} \mathrm{x}_{\mathrm{j}}$ but also deliver a certain proportion of products to be used by the final consumers or exported to non-residents. A linear equation system can be presented in matrix form, where:

$\mathrm{A}^{\mathrm{D}}=$ matrix of input coefficients for domestic intermediates (technology matrix comprising $n$ rows and $n$ columns, with elements $\mathrm{a}_{\mathrm{ij}}$ as defined in the previous paragraph, according to data availability $n=64$ in this study),

$\mathrm{I}=$ unit matrix ( $\mathrm{n} \mathrm{n}$ matrix with value 1 on the main diagonal and value 0 on the other cells),

$\left(I-A^{D}\right)=$ Leontief matrix for domestic inputs,

$\left(I-A^{D}\right)^{-1}=$ Leontief inverse for domestic inputs,

$\mathrm{f}^{\mathrm{D}}=$ vector of final demand (final expenditures of households, government, non-profit institutions serving households, gross investments, and exports),

$$
\mathrm{x}=\text { vector of output. }
$$

The following set of equations can be derived in the input-output model (Soklis 2009):

(1) $\quad \mathrm{A}^{\mathrm{D}} \mathrm{x}+\mathrm{f}^{\mathrm{D}}=\mathrm{x}$ (this single equation in matrix form summarised $n$ linear equation $1_{\mathrm{a}}$ to $1_{\mathrm{n}}$ )

(2) $x-A^{D} x=y$

(3) $\left(I-A^{D}\right) x=y$

The solution of this linear equation system is:

(4) $\mathrm{x}=\left(\mathrm{I}-\mathrm{A}^{\mathrm{D}}\right)^{-1} * \mathrm{y}$

Matrix algebra is further used in multiplying a matrix of unit inputs (domestic and intermediate consumption, employment, and value added) with the total domestic gross output induced by foreign demand:

(5) $\mathrm{V}=v^{*}\left(\mathrm{I}-\mathrm{A}^{\mathrm{D}}\right)^{-1} * \mathrm{y}$

$V$ is the value of inputs (vector of value added, intermediate consumption and employment) and $v$ is a technical input coefficient (input component per unit of output $-\mathrm{V} / \mathrm{Y})$.

Vector $\mathrm{A}^{\mathrm{D}} \mathrm{x}$ reflects the requirements for intermediates, while vector $\mathrm{y}$ represents the exogenous aggregate final demand. The matrix $\left(\mathrm{I}-\mathrm{A}^{\mathrm{D}}\right)$ is usually called the Leontief matrix for domestic products. On the diagonal of this matrix, the net output is given for each sector with positive coefficients (revenues), while the rest of the matrix covers the input requirements with negative coefficients (costs). The Leontief inverse for domestic production $\left(\mathrm{I}-\mathrm{A}^{\mathrm{D}}\right)^{-1}$ reflects direct and indirect requirements for intermediates. In the estimation of multiplicative effects on the domestic economy, it is crucial to identify the proportion of domestic intermediates that are used in the production process of an industry. The higher the share 
of domestic intermediate inputs, the more significant indirect effect is expected and vice versa.

The notion of multipliers rests upon the difference between the initial effect of an exogenous change in final demand (in our case, the change in foreign demand for manufacturing industry products) and the total effects of that change on the domestic economy. The intensity of backward linkages of certain economic sectors is usually defined as changes at the level of the economy produced by one unit change in a sector's final demand. It can be expressed in the form of a multiplier or as a percentage of indirect effects in the direct change of demand. An output multiplier for exports of the food industry is defined as the total value of production of all domestic sectors that is necessary to satisfy the value of final demand for the food sector. It is worth noting that a multiplier is effective in both directions. Deterioration in international competiveness, which induces export decrease, directly affects revenues of exporters, but also has a negative impact on other domestic industries that are part of the supply chain.

\section{RESULTS}

\subsection{CMS results}

The CMS effects - the total effect (TE), the competitiveness effect (CE), the product composition effect (PE), and the geographical distribution effect (GE) - have been calculated for the export of the Croatian food industry on the global market as well as separately for the EU-15, NMS-12, and CEFTA markets (Table 2). A positive value of individual effects indicates a gain in the market share of the Croatian food industry, while a negative value indicates a loss.

Regarding the total effect (TE) in the global market, negative signs are recorded in 2004 and in the period 2007-2013, which can be primarily attributed to the negative competitiveness effect (CE). It reveals the inability of the Croatian food industry to increase its market share due to competitiveness factors, independently of structural developments in the market or in the product trade patterns. However, the international competitiveness of the food industry improved substantially after the EU accession. In 2014 and 2015, CE and TE were estimated to be positive. A mild economic recovery of the EU markets (2010-2013) has not positively affected the exports of the Croatian food industry in the period 2010-2013. However, the continuation of economic growth in the main EU trading partners in 2014 and 2015, coupled with the full membership status that cancelled any non-tariff barrier for Croatian exports, contributed to the recovery in the export competitiveness of the Croatian food industry. The most significant 
Table 2. Export of the Croatian food industry - distribution of CMS effects in the period 2002-2015

\begin{tabular}{|c|c|c|c|c|c|}
\hline & TE & $\mathrm{CE}$ & PE & GE & $\mathrm{RE}$ \\
\hline \multicolumn{6}{|c|}{ WORLD } \\
\hline 2002 & 0.1633 & 0.1565 & -0.0301 & 0.0724 & -0.0355 \\
\hline 2003 & 0.2896 & 0.2918 & -0.0859 & -0.0321 & 0.1158 \\
\hline 2004 & -0.1849 & -0.1702 & -0.0827 & 0.2530 & -0.1851 \\
\hline 2005 & 0.2677 & 0.2457 & -0.0369 & 0.1635 & -0.1045 \\
\hline 2006 & 0.1993 & 0.1622 & -0.0377 & -0.0369 & 0.1118 \\
\hline 2007 & -0.1887 & -0.1314 & -0.1244 & 0.0355 & 0.0315 \\
\hline 2008 & -0.0772 & -0.0376 & -0.1196 & -0.0345 & 0.1146 \\
\hline 2009 & 0.0150 & -0.0382 & 0.0778 & 0.0402 & -0.0649 \\
\hline 2010 & -0.1588 & -0.1617 & -0.0672 & -0.0702 & 0.1403 \\
\hline 2011 & -0.0408 & -0.0045 & -0.1270 & -0.0264 & 0.1171 \\
\hline 2012 & -0.0278 & -0.0294 & -0.0023 & -0.0059 & 0.0098 \\
\hline 2013 & -0.1405 & -0.1317 & -0.0092 & -0.0150 & 0.0154 \\
\hline 2014 & 0.1678 & 0.1777 & -0.0026 & -0.0441 & 0.0368 \\
\hline 2015 & 0.0138 & 0.0237 & 0.0099 & -0.1036 & 0.0837 \\
\hline \multicolumn{6}{|c|}{ CEFTA } \\
\hline 2002 & -0.1143 & -0.1280 & 0.0055 & -0.2108 & 0.2190 \\
\hline 2003 & 0.1707 & -0.4762 & 0.0078 & 0.3547 & 0.2843 \\
\hline 2004 & -0.6562 & -0.6768 & -0.0039 & 0.0567 & -0.0323 \\
\hline 2005 & -0.2420 & -0.3376 & 0.0297 & 0.1284 & -0.0626 \\
\hline 2006 & 0.1357 & 0.1410 & 0.0413 & 0.1095 & -0.1561 \\
\hline 2007 & -0.0326 & -0.0233 & -0.0441 & -0.0624 & 0.0973 \\
\hline 2008 & 0.2185 & 0.2071 & -0.0172 & 0.0896 & -0.0610 \\
\hline 2009 & -0.0227 & -0.0420 & 0.0424 & 0.0242 & -0.0474 \\
\hline 2010 & -0.1007 & -0.0909 & 0.0044 & 0.0072 & -0.0214 \\
\hline 2011 & -0.0478 & -0.0332 & -0.0111 & 0.0063 & -0.0097 \\
\hline 2012 & -0.0354 & -0.0318 & 0.0040 & -0.0186 & 0.0110 \\
\hline 2013 & -0.0082 & -0.0049 & 0.0158 & -0.0022 & -0.0169 \\
\hline 2014 & 0.0880 & 0.0893 & -0.0024 & 0.0367 & -0.0356 \\
\hline 2015 & 0.0305 & 0.0266 & 0.0058 & -0.0084 & 0.0065 \\
\hline \multicolumn{6}{|c|}{ EU-15 } \\
\hline 2002 & 0.2643 & 0.2202 & 0.0306 & -0.0194 & 0.0329 \\
\hline 2003 & 0.8202 & 0.8243 & 0.0118 & 0.0203 & -0.0362 \\
\hline 2004 & -0.4563 & -0.5228 & 0.0400 & 0.0104 & 0.0161 \\
\hline 2005 & 0.8740 & 0.8785 & 0.0012 & 0.0027 & -0.0085 \\
\hline 2006 & 0.1453 & 0.1744 & -0.0088 & -0.0061 & -0.0141 \\
\hline 2007 & -0.2543 & -0.2770 & 0.0232 & -0.0077 & 0.0072 \\
\hline 2008 & -0.3980 & -0.3662 & -0.0045 & -0.0168 & -0.0105 \\
\hline 2009 & -0.0334 & -0.0729 & 0.0109 & 0.0103 & 0.0182 \\
\hline 2010 & 0.0322 & 0.0361 & 0.0011 & 0.0063 & -0.0113 \\
\hline
\end{tabular}


Table 2. continued

\begin{tabular}{l|r|r|r|r|r}
\hline & TE & CE & PE & GE & \multicolumn{1}{c}{ RE } \\
\hline 2011 & -0.0150 & -0.0644 & 0.0481 & -0.0146 & 0.0159 \\
\hline 2012 & -0.0245 & -0.0156 & -0.0120 & -0.0143 & 0.0174 \\
\hline 2013 & -0.1326 & -0.1682 & 0.0271 & -0.0053 & 0.0137 \\
\hline 2014 & 0.2044 & 0.2158 & -0.0011 & -0.0209 & 0.0106 \\
\hline 2015 & 0.1637 & 0.1699 & -0.0006 & -0.0120 & -0.0177 \\
\hline NMS-12 & 0.0763 & 0.0511 & 0.0685 & -0.0025 & -0.0408 \\
\hline 2002 & -0.0661 & -0.0681 & 0.1062 & -0.0134 & -0.0907 \\
\hline 2003 & -0.3391 & -0.3491 & 0.1585 & -0.0442 & -0.1042 \\
\hline 2004 & 0.3135 & 0.3170 & 0.1061 & -0.0377 & -0.0719 \\
\hline 2005 & 0.5221 & 0.4731 & 0.1084 & -0.0041 & -0.0553 \\
\hline 2006 & -0.4687 & -0.3806 & 0.1104 & -0.0006 & -0.1979 \\
\hline 2008 & 0.0827 & -0.346 & 0.2072 & -0.0717 & -0.0183 \\
\hline 2009 & -0.0480 & -0.1121 & -0.0182 & 0.0155 & 0.0667 \\
\hline 2010 & -0.1453 & -0.1298 & 0.0110 & -0.0579 & 0.0315 \\
\hline 2011 & -0.0017 & -0.0899 & 0.1459 & -0.0107 & -0.0469 \\
\hline 2012 & 0.0765 & 0.0842 & -0.0111 & -0.0386 & 0.0421 \\
\hline 2013 & -0.2646 & -0.1359 & -0.0300 & -0.0214 & -0.0772 \\
\hline 2014 & 0.5322 & 0.5862 & -0.0058 & 0.0182 & -0.0664 \\
\hline & 0.1729 & 0.2077 & -0.0361 & 0.0759 & -0.0746 \\
\hline
\end{tabular}

Source: Authors' calculations based on UN COMTRADE Database.

growth in export competitiveness regarding EU-15 (CE=0.2158) and NMS-12 $(\mathrm{CE}=0.5862)$ markets was recorded in 2014.

Although the product effect (PE) was negative in some years in the period 2010-2015, it is very close to zero. It can be concluded that the product mix of exported food products on the European market (CEFTA, EU-15, and NMS-12) is not an obstacle for export expansion. The Croatian export of food products is concentrated on commodities in which European demand is relatively stable, even in the periods of economic crisis.

The geographical effect was mostly negative in the period 2011-2015. It reveals an unfavourable geographical export structure of the Croatian food industry due to a high export concentration to markets in which demand is growing slower (Bosnia and Herzegovina, Slovenia, and Italy) in comparison to the world market ${ }^{6}$.

6 In 2015, Bosnia and Herzegovina, Italy, and Slovenia accounted for $46 \%$ of the total export of the Croatian food industry. 
In general, it is obvious that the loss or gain of competitiveness of the Croatian food industry is the most important factor, which determines its share of international market. The impact of product structure is more or less neutral, while the regional reorientation of export to countries with a stable growth of international trade could be helpful for the export performance of the Croatian food industry.

Besides identifying different effects on the level of the total food industry, the CMS model is able to give insight into export performance among various product groups included in the agri-food sector. In the period from 2001 to 2015, most product groups recorded a growth of export shares in total world exports. These products represent a significant part of the total export structure of the Croatian food industry. The distribution of the competitiveness effect (CE) and the product effect (PE) according to products reveals the positive values of those effects in most products (Table 3 ).

The results obtained (Table 4) indicate that major products were able to compete on CEFTA and EU markets. Fish products exhibited the most significant growth, even during the recession period, with positive competitiveness and product effects. At the same time, the results of the CMS analysis demonstrated that the differentiated growth of world import demand across products and destinations had contributed to the Croatian food industry specialised in fast-growing products and export markets, to compensate for the loss of export competitiveness in other product groups.

Although the competitive edge of the food industry in the Croatian economy is improving, a multiplying effect, in terms of the total economy, gross value added, and employment, remains stable. These effects are more thoroughly analysed in the following section.

\subsection{Input-output analysis results}

Table 6 presents a comparison of the multiplier by different sectors of the Croatian economy. The multiplier of gross output presents the ratio between direct and indirect increase in gross output, which is attributable to the initial increase of production. In the case of the food industry, an increase in foreign demand of 1 unit (in monetary terms) induces the total growth of the domestic gross output of 1.956 units. In comparison to the national average, it could be noted that the multiplier of the food industry is relatively high. In general, technological processes are more complex in sectors that produce physical products (agriculture, industry, construction). Services are mainly labour-intensive industries which could be delivered without significant and complex input produced by other industries, and indirect effects are limited. 


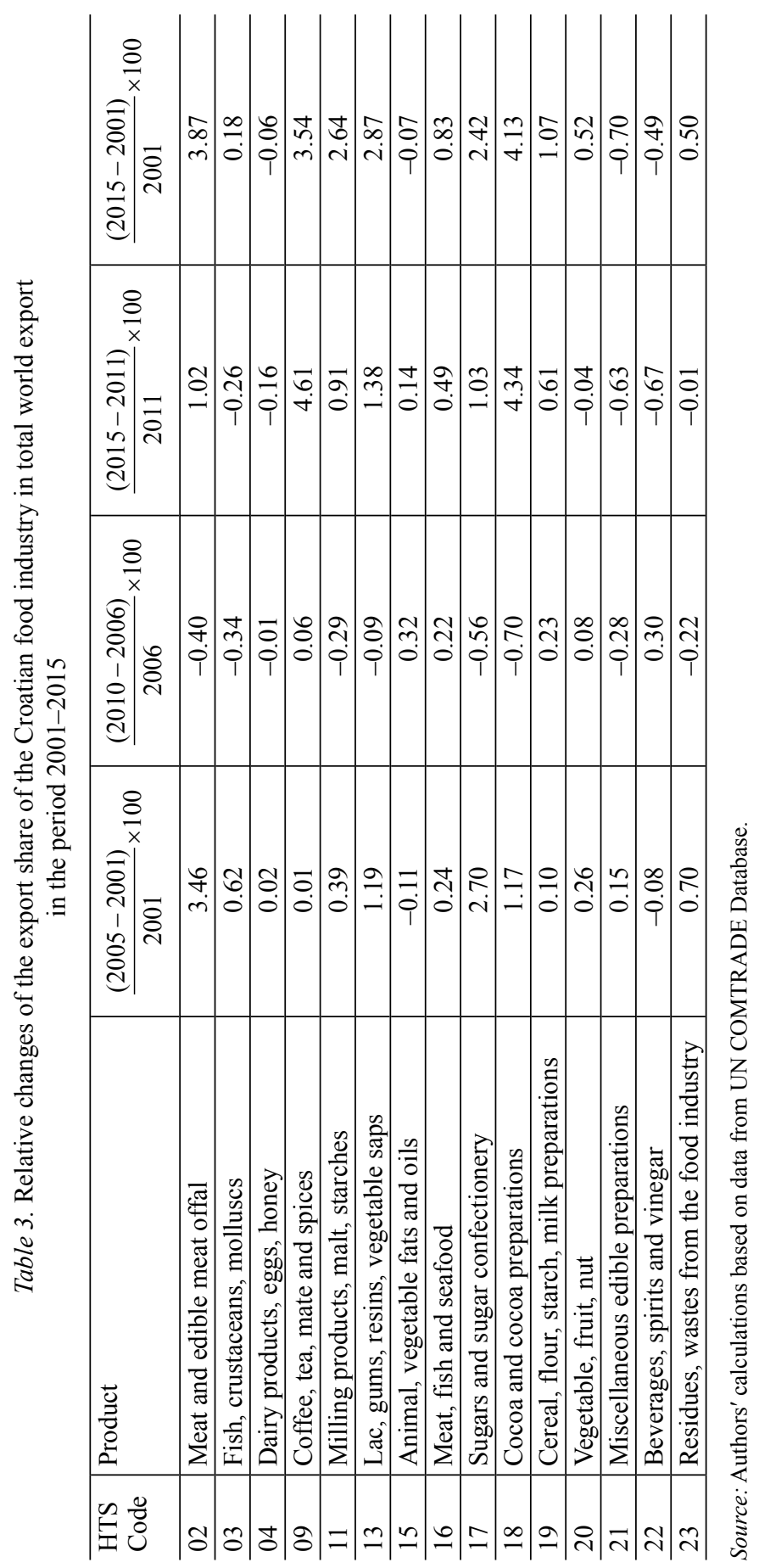




\begin{tabular}{|c|c|c|c|c|c|c|c|c|c|c|c|c|c|c|c|c|}
\hline$\frac{N}{1}$ & $\frac{1}{2}$ & $\begin{array}{l} \pm \\
\\
\Xi \\
\dot{0}\end{array}$ & $\mid \begin{array}{l}\text { ㄱ. } \\
8 \\
8 \\
\dot{0}\end{array}$ & $\begin{array}{l}\overline{8} \\
8 \\
0 \\
\dot{9}\end{array}$ & 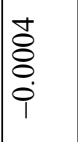 & $\begin{array}{l}0 \\
0 \\
\varnothing \\
0 \\
0 \\
0\end{array}$ & 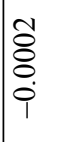 & 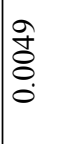 & $\begin{array}{l}\overline{1} \\
\tilde{8} \\
0 \\
0\end{array}$ & $\begin{array}{l}\infty \\
0 \\
\wp \\
0 \\
0\end{array}$ & $\begin{array}{l}\text { 오 } \\
\text { ㅇ. } \\
\text { ○ } \\
0\end{array}$ & $\begin{array}{l}0 \\
0 \\
8 \\
0 \\
0\end{array}$ & $\left|\begin{array}{c}\infty \\
0 \\
\varnothing \\
0 \\
0\end{array}\right|$ & $\begin{array}{l}\bar{\sigma} \\
8 \\
8 \\
0\end{array}$ & $\begin{array}{l}\text { 尹 } \\
\text { ठ } \\
\dot{0}\end{array}$ & 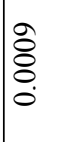 \\
\hline$\overline{\mathbf{Z}}$ & 岂 & 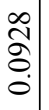 & $\mid \begin{array}{l}0 \\
i n \\
0 \\
0 \\
0\end{array}$ & $\begin{array}{l}\sigma \\
0 \\
0 \\
0\end{array}$ & $\frac{\infty}{\infty}$ & $\begin{array}{l}n \\
m \\
0 \\
0\end{array}$ & 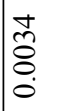 & $\frac{\hat{\sigma}}{\hat{0}}$ & 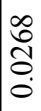 & $\frac{\hat{n}}{0}$ & $\begin{array}{l}\bar{g} \\
\dot{J} \\
0\end{array}$ & $\begin{array}{l}= \\
0 \\
0\end{array}$ & 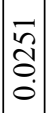 & 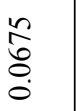 & $\frac{N}{0}$ & 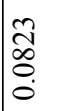 \\
\hline$\frac{n}{1}$ & $\mid \underline{\underline{2}}$ & $\begin{array}{l}5 \\
8 \\
8 \\
\dot{0}\end{array}$ & $\left|\begin{array}{c}\mathfrak{O} \\
\stackrel{\Xi}{\Xi} \\
\dot{0}\end{array}\right|$ & $\begin{array}{l}0 \\
\\
\delta \\
0 \\
0\end{array}$ & $\frac{n}{2}$ & $\begin{array}{l}\hat{m} \\
0 \\
0 \\
0\end{array}$ & $\begin{array}{l}0 \\
\bar{Z} \\
0 \\
0\end{array}$ & $\begin{array}{l}\begin{array}{r} \pm \\
0 \\
\dot{1}\end{array} \\
\end{array}$ & $\begin{array}{l}\text { J } \\
8 \\
8 \\
\dot{0}\end{array}$ & $\begin{array}{l}\infty \\
\infty \\
0 \\
0 \\
0\end{array}$ & $\begin{array}{l}\bar{\sigma} \\
\delta \\
\dot{\delta} \\
\dot{1}\end{array}$ & 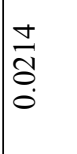 & $\mid \begin{array}{l}\widehat{N} \\
\delta \\
\delta \\
0 \\
0\end{array}$ & $\begin{array}{l}\frac{0}{2} \\
\frac{n}{0} \\
0\end{array}$ & $\begin{array}{l}8 \\
8 \\
8 \\
0\end{array}$ & $\mid \begin{array}{l}\infty \\
\infty \\
8 \\
0 \\
0\end{array}$ \\
\hline 디 & 四 & $\begin{array}{l}\stackrel{n}{\Im} \\
\stackrel{\Xi}{0} \\
\dot{0}\end{array}$ & $\left|\begin{array}{l}\infty \\
\hdashline \\
\dot{a} \\
\dot{0}\end{array}\right|$ & $\begin{array}{l}\overline{8} \\
8 \\
0 \\
0\end{array}$ & 文 & \begin{tabular}{l}
0 \\
\hdashline \\
\\
0
\end{tabular} & 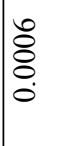 & $\begin{array}{l}n \\
0 \\
0 \\
0\end{array}$ & $\begin{array}{l}\mathfrak{g} \\
\dot{J} \\
\dot{0}\end{array}$ & 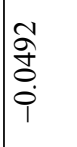 & N & $\frac{1}{0}$ & $\left|\begin{array}{c}0 \\
0 \\
0 \\
0 \\
0\end{array}\right|$ & 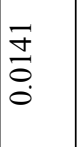 & $\begin{array}{l}m \\
0 \\
0 \\
0 \\
0\end{array}$ & 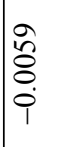 \\
\hline$\underset{\leftarrow}{\leftarrow}$ & $\frac{1}{2}$ & 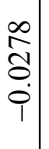 & $\left|\begin{array}{l}\infty \\
\bar{a} \\
\text { in }\end{array}\right|$ & $\begin{array}{l}0 \\
\infty \\
0 \\
0 \\
0\end{array}$ & $\frac{n}{2}$ & $\begin{array}{l}0 \\
8 \\
0 \\
0 \\
0 \\
\end{array}$ & $\begin{array}{l}0 \\
\stackrel{8}{0} \\
0 \\
0 \\
0\end{array}$ & $\begin{array}{l}\bar{\infty} \\
\overline{0} \\
\dot{1}\end{array}$ & 合 & $\frac{a}{0}$ & 寺 & 尚 & $\left|\begin{array}{c}0 \\
\infty \\
0 \\
0 \\
0 \\
0\end{array}\right|$ & $\begin{array}{l}\hat{\infty} \\
\text { OV } \\
0 \\
0\end{array}$ & $\begin{array}{l}\text { J } \\
\text { ठ } \\
0 \\
0\end{array}$ & ஓे \\
\hline$\cup$ & 号 & $\begin{array}{l}\bar{E} \\
\overline{0} \\
\dot{0}\end{array}$ & $\left|\begin{array}{l}0 \\
n \\
0 \\
0 \\
0\end{array}\right|$ & 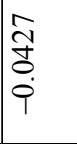 & 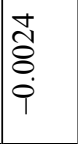 & $\begin{array}{l}\overrightarrow{0} \\
\stackrel{8}{8} \\
\dot{0}\end{array}$ & $\begin{array}{l}0 \\
\varnothing \\
\varnothing \\
\varnothing \\
0\end{array}$ & 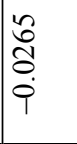 & $\begin{array}{l}n \\
1 \\
8 \\
0 \\
0\end{array}$ & $\begin{array}{l}\tilde{N} \\
\tilde{0} \\
\dot{9}\end{array}$ & 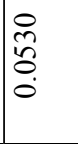 & $\mid \begin{array}{l}\infty \\
+ \\
0 \\
0\end{array}$ & $\left|\begin{array}{l}0 \\
0 \\
8 \\
0 \\
0\end{array}\right|$ & $\begin{array}{l}\bar{\infty} \\
\text { J } \\
\dot{0}\end{array}$ & ○े & İ \\
\hline$\stackrel{\theta}{\beta}$ & $\frac{1}{2}$ & 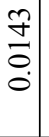 & 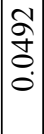 & $\begin{array}{l}\hat{\infty} \\
\dot{+} \\
0 \\
0\end{array}$ & 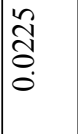 & 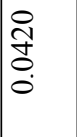 & $\begin{array}{l}n \\
\text { ป̂ } \\
\text { d } \\
0\end{array}$ & $\begin{array}{l}0 \\
\infty \\
0 \\
0 \\
0 \\
0\end{array}$ & $\begin{array}{l}n \\
\tilde{n} \\
\delta \\
0\end{array}$ & $\frac{m}{\mathscr{J}}$ & $\begin{array}{l}\tilde{\omega} \\
\tilde{\sigma} \\
0 \\
0\end{array}$ & $\begin{array}{l}\mathcal{N} \\
\mathscr{J} \\
0 \\
0\end{array}$ & 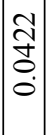 & $\begin{array}{l}\stackrel{g}{2} \\
\stackrel{2}{\circ} \\
0\end{array}$ & $\frac{0}{1}$ & 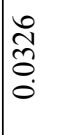 \\
\hline 3 & பு & 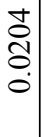 & 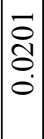 & $\frac{\bar{m}}{\overline{0}}$ & $\frac{\infty}{\sigma}$ & 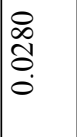 & 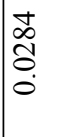 & $\begin{array}{l}9 \\
0 \\
8 \\
0 \\
0\end{array}$ & 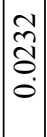 & $\begin{array}{l}\mathbf{J} \\
\mathbf{8} \\
0 \\
0\end{array}$ & $\begin{array}{l}0 \\
\Xi \\
0 \\
0\end{array}$ & 孚 & $\mid \begin{array}{l}\tilde{\gamma} \\
\delta \\
0 \\
0\end{array}$ & 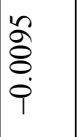 & 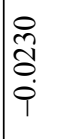 & \begin{tabular}{l}
0 \\
\hdashline \\
0 \\
0 \\
0
\end{tabular} \\
\hline 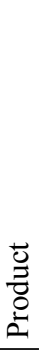 & & 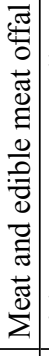 & 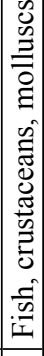 & 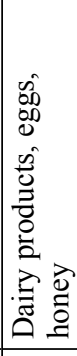 & 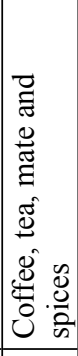 & 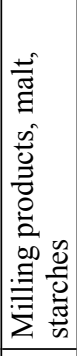 & 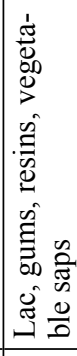 & 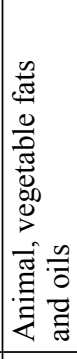 & 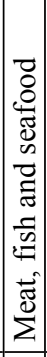 & 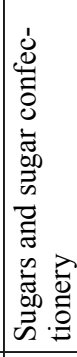 & 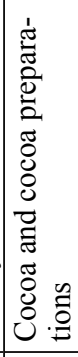 & 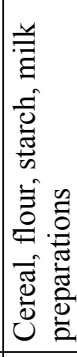 & 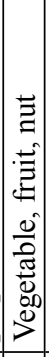 & 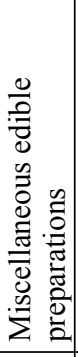 & 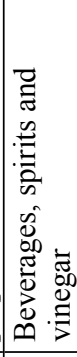 & 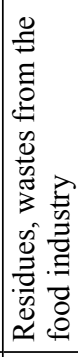 \\
\hline$\stackrel{\mathscr{I}}{\mathcal{I}}$ & & $\sqrt{0}$ & 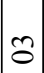 & $\Xi$ & 8 & $=$ & $-i$ & $\cong$ & 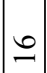 & I & $\infty$ & 2 & గ్ల & $\vec{\sim}$ & ป & $\widehat{\curvearrowright}$ \\
\hline
\end{tabular}


Table 5. Output, value added, and employment multipliers in the Croatian economy, position of the food industry in 2004, NACE 2002 classification

\begin{tabular}{|c|c|c|c|c|c|c|c|c|}
\hline 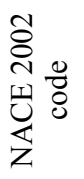 & $\stackrel{m}{\&}$ & 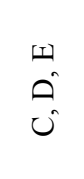 & $\omega$ & $\begin{array}{l}I \\
0\end{array}$ & $\stackrel{\mathscr{}}{\stackrel{G}{\leftrightarrows}}$ & $\sum_{i}^{2}$ & 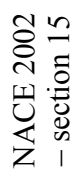 & 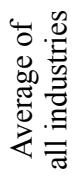 \\
\hline & 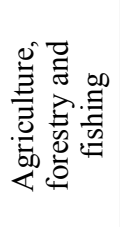 & 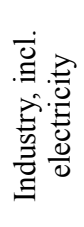 & $\begin{array}{l}.0 \\
0 \\
0 \\
0 \\
0 \\
0 \\
0 \\
0\end{array}$ & 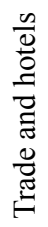 & 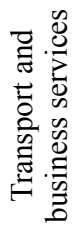 & 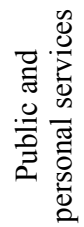 & 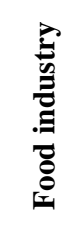 & 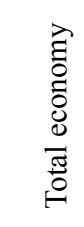 \\
\hline
\end{tabular}

\begin{tabular}{l|l|l|l|l|l|l|l|l}
\hline \multicolumn{1}{c}{ Gross output } \\
\hline Direct impact & 1.000 & 1.000 & 1.000 & 1.000 & 1.000 & 1.000 & 1.000 & 1.000 \\
\hline Total impact & 1.776 & 1.749 & 1.871 & 1.616 & 1.575 & 1.485 & 1.956 & 1.652 \\
\hline Multiplier & 1.776 & 1.749 & 1.871 & 1.616 & 1.575 & 1.485 & 1.956 & 1.652 \\
\hline \multicolumn{8}{|c}{ Value added } \\
\hline Direct impact & 0.512 & 0.368 & 0.359 & 0.525 & 0.532 & 0.592 & 0.353 & 0.443 \\
\hline Total impact & 0.877 & 0.695 & 0.723 & 0.812 & 0.831 & 0.847 & 0.777 & 0.763 \\
\hline Multiplier & 1.712 & 1.892 & 2.012 & 1.546 & 1.561 & 1.431 & 2.201 & 1.723 \\
\hline
\end{tabular}

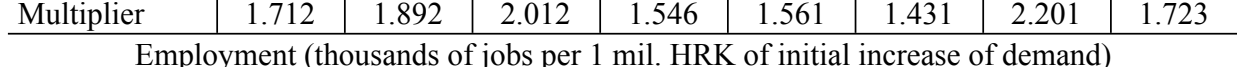

\begin{tabular}{l|l|l|l|l|l|l|l|l}
\hline Direct impact & 3.6 & 2.3 & 2.7 & 5.0 & 1.9 & 7.5 & 2.2 & 2.9 \\
\hline Total impact & 6.1 & 4.5 & 4.9 & 6.9 & 3.9 & 9.9 & 4.3 & 5.4 \\
\hline Multiplier & 1.7 & 2.0 & 1.9 & 1.4 & 2.0 & 1.3 & 1.9 & 1.8 \\
\hline
\end{tabular}

Source: Authors' calculations based on data from Eurostat.

Table 5 (multipliers in 2004) and Table 6 (multipliers in 2010) present an impact of increased demand on the domestic gross value added, which is defined as a gross output minus intermediate consumption. The direct impact of export demand on the value added reflects the share of value added in the gross output of an exporting company. In order to produce one unit of gross output, food producers need to spend, on average, approximately $65 \%$ of revenues on intermediary consumption (raw agriculture products, energy, transport services) and the rest presents the value added, which is to be distributed to income categories: gross wages and salaries, taxes, and gross operating surplus. However, the gross value added in other industries included in the supply chain of the agri-food sector also increases the value added multiplier for the food industry to 2.2 , meaning that the value added of other domestic companies increases even more than the value added of the direct exporter.

Besides intermediary inputs, in order to produce additional food products in accordance to orders received from abroad, exporters usually need to hire more 
Table 6. Output, value added, and employment multipliers in the Croatian economy, position of the food industry in 2010, NACE 2007 classification

\begin{tabular}{|c|c|c|c|c|c|c|c|c|}
\hline 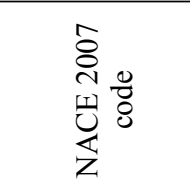 & $\varangle$ & $\begin{array}{l}\text { जी } \\
\text { 0े } \\
0\end{array}$ & I & $\tilde{\bullet}$ & $\begin{array}{l}\hat{n} \\
\hat{y} Z \\
\hat{\Xi} \Sigma \\
\dot{I}\end{array}$ & 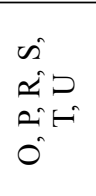 & 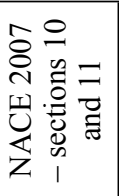 & 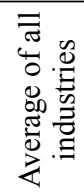 \\
\hline & 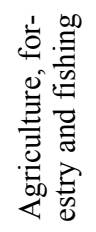 & 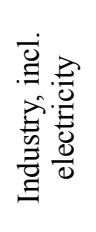 & 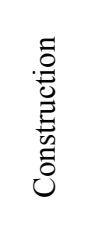 & 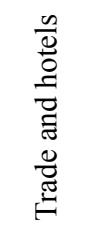 & 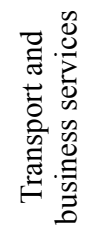 & 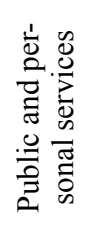 & 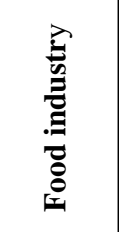 & 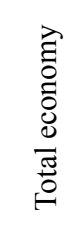 \\
\hline \multicolumn{9}{|c|}{ Gross output } \\
\hline Direct impact & 1.000 & 1.000 & 1.000 & 1.000 & 1.000 & 1.000 & 1.000 & 1.000 \\
\hline Total impact & 1.537 & 1.599 & 1.680 & 1.530 & 1.495 & 1.431 & 1.808 & 1.529 \\
\hline Multiplier & 1.537 & 1.599 & 1.680 & 1.530 & 1.495 & 1.431 & 1.808 & 1.529 \\
\hline \multicolumn{9}{|c|}{ Value added } \\
\hline Direct impact & 0.574 & 0.358 & 0.379 & 0.540 & 0.575 & 0.609 & 0.341 & 0.506 \\
\hline Total impact & 0.840 & 0.634 & 0.738 & 0.810 & 0.827 & 0.835 & 0.733 & 0.760 \\
\hline Multiplier & 1.464 & 1.772 & 1.947 & 1.501 & 1.438 & 1.372 & 2.148 & 1.503 \\
\hline \multicolumn{9}{|c|}{ Employment (per HRK 1 mill. of initial increase of demand) } \\
\hline Direct impact & 3.0 & 2.6 & 2.4 & 3.9 & 2.6 & 4.5 & 1.7 & 3.0 \\
\hline Total impact & 4.7 & 4.3 & 4.0 & 5.4 & 4.0 & 5.9 & 3.8 & 4.6 \\
\hline Multiplier & 1.6 & 1.6 & 1.7 & 1.4 & 1.5 & 1.3 & 2.2 & 1.5 \\
\hline
\end{tabular}

Source: Authors' calculations based on data from Eurostat.

labour. The last part of Table 6 presents additional employment for thousands of people, who are to be engaged as a result of increased production. On average, production in the value of HRK 1 million requires 2.9 thousand people to be directly engaged. The total direct and indirect employment includes jobs created in the overall domestic supply chain and is estimated to 5.4 thousand per HRK 1 million in the initial increase in value of production. In general, the industry sector, including the food industry, is more capital-intensive and the number of people employed induced by the increase in demand is lower in comparison to the service sector.

It is interesting to note that the 2010 multipliers are lower in comparison to 2004, which indicates a less intensive interconnection between domestic producers. It is interesting to note that multipliers are lower in all sectors of the national economy, while the most pronounced impact can be found in agriculture and in industry. The difference between producers of physical goods and services is not pronounced in 2010. The food industry multiplier is also reduced, but in smaller proportions than in the total manufacturing industry. 
The employment multiplier for the food industry increased by 2010, while this indicator decreased in all other sectors. However, a productivity growth factor is behind the result that HRK 1 million of final products could be delivered both directly and indirectly using less engaged labour.

In general, multipliers reflect the intensity of interrelationship between domestic producers and the complexity of the supply chain. A change in multipliers is the consequence of technological improvements, but also reflects an overall competitiveness of national producers. If competitiveness decreases, domestic producers will engage more imported inputs and vice versa. In the case of the food industry, Table 7 supports the hypothesis that in the case of the food industry, a lower multiplier is attributable to a higher share of imported intermediate products. Although the share of value added in gross output remains at approximately $35 \%$, it can be noted that the share of domestic intermediates declines from 53 to $49 \%$ of gross value added, while imported intermediates increased on the account of domestic producers along the overall supply chain.

The most important inputs in the food industry are raw agricultural products. The export of processed and more complex food products can therefore also induce improvements in the position of farmers and other producers of agricultural products, and provide an opportunity to indirectly supply their products on the EU market, which is highly regulated.

A more significant role of foreign intermediary inputs by domestic food producers is not only a characteristic of the Croatian economy. Although higher in 2010, the share of imported intermediates used in the food industry in Croatia is still below the average recorded in NMSs. In the group of analysed countries, the highest share of imported intermediates are recorded in Estonia and Slovenia (Table 8). In all NMSs and, especially in Estonia and Slovenia, the food industry is more oriented to intra-industrial international cooperation and the share of imported food products used as intermediates is significantly higher than imported raw agricultural products. On the other hand, data for Croatia indicates that the process of intra-industry, international cooperation was absolutely absent in 2010 and the share of imported food products and beverages was very low. The pattern of vertical integration of the food industry supply chain is even more dominant today than in 2004 regarding both the domestic and the foreign component. 
Table 7. The main intermediary inputs in the Croatian food industry

\begin{tabular}{|c|c|c|c|c|c|}
\hline & 2004 & & 2010 & & \\
\hline & $\stackrel{v}{\underline{a}} \overline{\bar{\Xi}}$ & 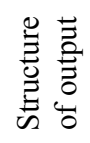 & $\underline{\underline{a}} \bar{\Xi}$ & 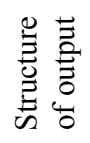 & 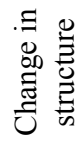 \\
\hline Output at basic prices & 25.089 & 100,0 & 32.710 & 100,0 & $\mathbf{0 , 0}$ \\
\hline Domestic intermediates & 13.392 & 53,4 & 16.103 & 49,2 & $-4,1$ \\
\hline $\begin{array}{l}\text { Products of agriculture, hunting, and } \\
\text { related services }\end{array}$ & 5.723 & 22,8 & 5.441 & 16,6 & $-6,2$ \\
\hline Food products and beverages & 2.218 & 8,8 & 663 & 2,0 & $-6,8$ \\
\hline Rubber and plastic products & 468 & 1,9 & 416 & 1,3 & $-0,6$ \\
\hline $\begin{array}{l}\text { Electric energy, gas, steam, } \\
\text { and hot water }\end{array}$ & 668 & 2,7 & 510 & 1,6 & $-1,1$ \\
\hline $\begin{array}{l}\text { Wholesale trade and commission trade } \\
\text { services }\end{array}$ & 1.197 & 4,8 & 1.329 & 4,1 & $-0,7$ \\
\hline Other business services & 494 & 2,0 & 780 & 2,4 & 0,4 \\
\hline Pulp, paper, and paper products & 286 & 1,1 & 406 & 1,2 & 0,1 \\
\hline Retail trade services & 8 & 0,0 & 1.220 & 3,7 & 3,7 \\
\hline Other domestic intermediates & 2.338 & 9,3 & 5.337 & 16,3 & 7,0 \\
\hline Imported intermediates & 3.044 & 12,1 & 5.398 & 16,5 & 4,4 \\
\hline $\begin{array}{l}\text { Products of agriculture, hunting, and } \\
\text { related services }\end{array}$ & 795 & 3,2 & 803 & 2,5 & $-0,7$ \\
\hline Food products and beverages & 1.196 & 4,8 & 309 & 0,9 & $-3,8$ \\
\hline Rubber and plastic products & 236 & 0,9 & 582 & 1,8 & 0,8 \\
\hline $\begin{array}{l}\text { Electric energy, gas, steam, } \\
\text { and hot water }\end{array}$ & 4 & 0,0 & 92 & 0,3 & 0,3 \\
\hline $\begin{array}{l}\text { Wholesale trade and commission trade } \\
\text { services, except motor vehicles and } \\
\text { motorcycles }\end{array}$ & 73 & 0,3 & 0 & 0,0 & $-0,3$ \\
\hline Other business services & 138 & 0,6 & 195 & 0,6 & 0,0 \\
\hline Pulp, paper, and paper products & 196 & 0,8 & 332 & 1,0 & 0,2 \\
\hline Mining and quarrying & 0 & 0,0 & 954 & 2,9 & 2,9 \\
\hline $\begin{array}{l}\text { Chemicals, chemical products, } \\
\text { and man-made fibres }\end{array}$ & 110 & 0,4 & 721 & 2,2 & 1,8 \\
\hline Other imported intermediates & 408 & 1,6 & 1.410 & 4,3 & 2,7 \\
\hline Value added & 8.851 & 35,3 & 11.485 & 35,1 & $-0,2$ \\
\hline
\end{tabular}

Source: Authors' calculations based on data from Eurostat. 


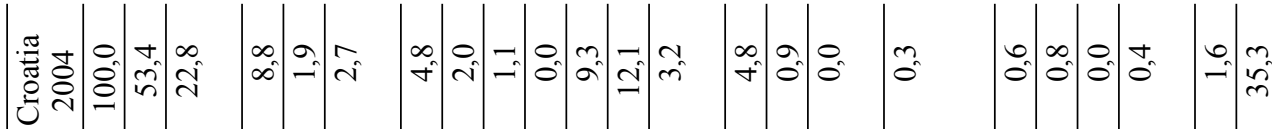

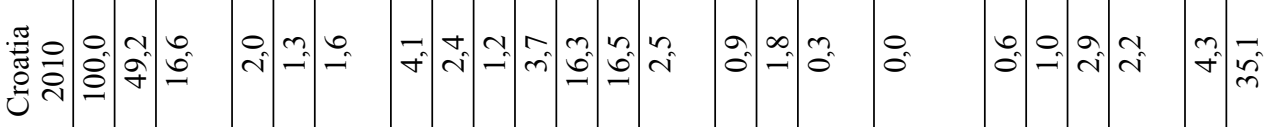

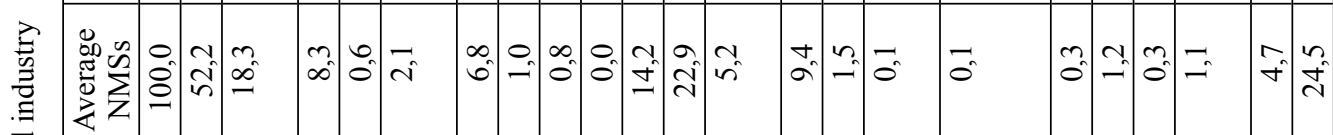
$\overline{8}$

\begin{tabular}{|c|c|c|c|c|c|c|c|c|c|c|c|c|c|c|c|c|c|c|c|c|c|c|}
\hline 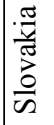 & $\mid \begin{array}{l}0 \\
0 \\
0 \\
0\end{array}$ & $\begin{array}{c}0 \\
\dot{q}\end{array} \mid$ & $\underset{ \pm}{ \pm}$ & $\stackrel{\Delta}{\sim}$ & $\begin{array}{l}0 \\
0 \\
0\end{array}$ & $\hat{\text { ते }}$ & o. & $\stackrel{\sim}{\sim}$ & : & $\begin{array}{l}0 \\
0\end{array}$ & $\hat{n}$ & 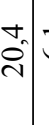 & $\overrightarrow{0}$ & 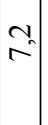 & $\stackrel{\Delta}{*}$ & : & $\tilde{0}$ & $\overrightarrow{0}$ & $\stackrel{0}{\infty} \mid \overrightarrow{0}$ & $\Rightarrow$ & $\begin{array}{l}\vec{j} \\
i\end{array}$ & $\begin{array}{c}+ \\
\stackrel{n}{n}\end{array}$ \\
\hline 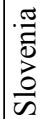 & $\begin{array}{l}0 \\
8 \\
0\end{array}$ & $\begin{array}{c}n \\
f \\
f\end{array} \mid$ & $\vec{\cong}$ & $\begin{array}{l}n \\
\infty\end{array} \mid$ & $\begin{array}{l}0 \\
0\end{array}$ & $\cong$ & 2 & $\left|\begin{array}{l}\infty \\
0\end{array}\right|$ & ?. & $\stackrel{0}{0}$ & $\overrightarrow{6}$ & $\begin{array}{l}\infty \\
\hat{N}\end{array}$ & ?n & $\begin{array}{c}0 \\
\text { fin }\end{array} \mid$ & $\therefore \bar{c}$ & $\vec{\sigma}_{0}$ & $\overrightarrow{0}$ & $\overrightarrow{0}$ & $\begin{array}{lll}0 & ? \\
0\end{array}$ & $\tilde{0}$ & $\begin{array}{l}+ \\
\infty \\
\infty\end{array}$ & 公 \\
\hline
\end{tabular}
$\Xi$

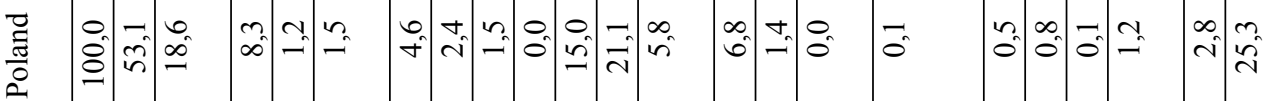

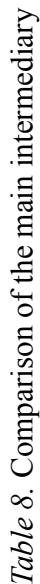

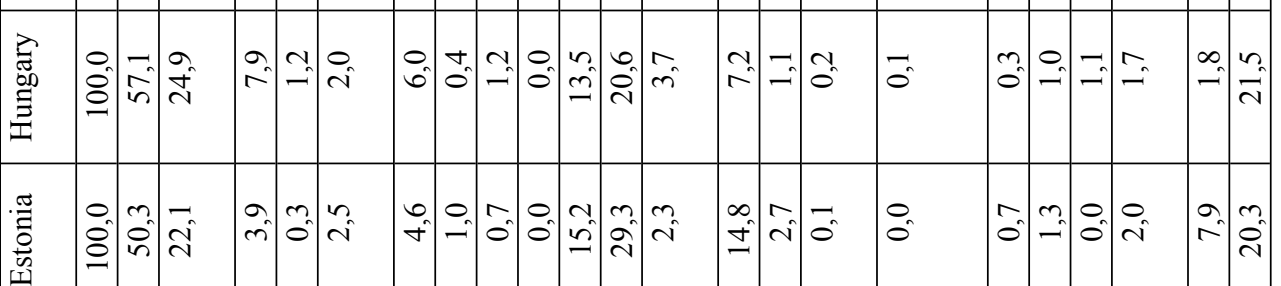

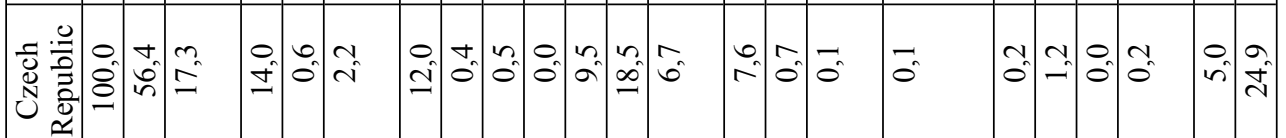

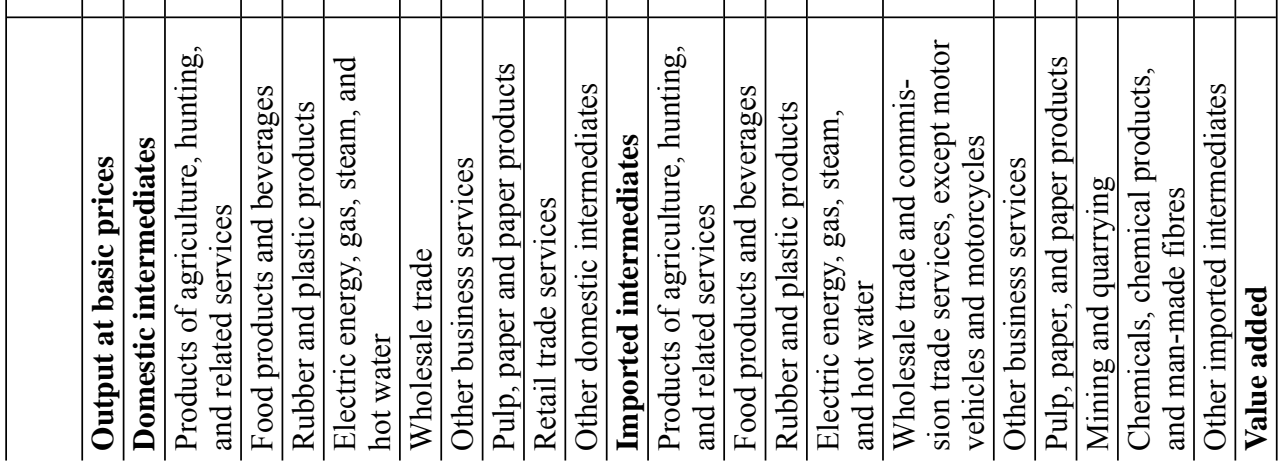

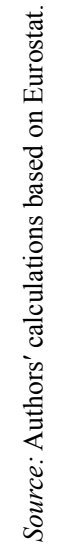




\section{DISCUSSION AND CONCLUDING REMARKS}

The export orientation of the Croatian food industry, measured as the export share in the gross value added, showed a relatively satisfactory performance in the pre-recession period. This result is consistent with previous research (Bojnec Fertö 2007). The Croatian food industry also presented a certain resistance to the recession that started in 2008. However, the trends in the period between 2009 until the EU membership (2013) confirmed a deterioration of export performance, which was primarily the consequence of decreasing export competitiveness. The trends were characterised by a significant decrease in exporting food products and a high level of export concentration regarding both the product and geographical structure. Based on the constant market share method, it could be concluded that the export performance of the Croatian food industry was deteriorating in all international market segments. A suboptimal export performance is more related to loss in competitiveness than product structure, especially on EU-15 and NMS-12 markets. Besides the loss of the export competitiveness, an unfavourable geographical export structure and a high level of export concentration to stagnant markets contributed to the negative geographical effects. An insufficient diversification of product and market structures revealed the unutilised potentials that could be overcome by new investments, primarily in market research and innovation activities. Research results pointing to the erosion of export competitiveness of the Croatian food industry in the period prior to the EU accession were consistent with studies which included Croatia and covered the same period (Ignjatijević et al. 2015) and studies which found a common conclusion on the lack of comparative advantage for most EU countries on the global market (Bojnec - Fertö 2015). The dynamics of Croatian exports set Croatia in the group of countries which could be classified as lagging behind in the export performance of the food industry, which consists of France, Belgium, Denmark, and Greece (Carraresi - Banterle 2015).

However, recent developments after the EU accession in 2013 regarding the competitiveness of the Croatian food industry were much more favourable and encouraging. This could be explained by the removal of all non-tariff barriers after the EU accession and reorientations towards foreign markets. As for different groups of products from the food industry, fish products exhibited the most significant growth even during the recession period, with positive competitiveness and product effect. A specialisation towards a more dynamic market and a reorientation to the export of food products with a higher share of value added were crucial factors for the further increase of the international competitiveness of the Croatian food industry. Most countries in the South-Eastern European region were more successful in restructuring their food industry towards the dy- 
namics of the EU market (Bojnec - Fertö 2010b) and Croatian food producers had to put in additional efforts to fully exploit the advantages related to EU membership, which could boost comparative advantages in comparison to regional competitors. Export results since the Croatian EU accession in 2013 have met such expectations and followed the theoretical predictions.

According to the results of the input-output analysis, the food industry is highly integrated with other sectors of the national economy and trends in the export of food products significantly impact economic developments of industries which produce intermediate inputs used in the production processes of the food industry. The multipliers of gross output, gross value added, and employment are estimated to be in the range between 1.8 and 2.2, which means that an initial increase of foreign demand not only affects food producers, but that they are doubled during the initial impulse which is spread over the entire economy. Similar to the previous studies, backward linkages for the food industry in Croatia are estimated to be more intense than the average of all sectors (Balla 2014; Šidlauskaitè - Miškinis 2013). The indirect effects induced by the growth of the food industry in Croatia are higher in comparison to Lithuania and Slovakia, but lower than in other Baltic States and Hungary. Although globalisation and the inclusion of domestic producers in international supply chains reduces the share of domestic intermediate consumption and therefore reduces indirect positive impact on the overall domestic economy, results indicate that the multiplier for the food sector decreased less than the national average. Improvements in the international competitiveness of the Croatian food sector could therefore significantly contribute to the overall economic recovery.

In the end, some important limitations of the study must be taken into account. The CMS analysis identified the sources of the export competitiveness of the Croatian food industry only at the macro level. This study could not involve a micro level analysis that could ensure deeper insights into the reasons of structural changes in export competitiveness due to the nature of the research, data availability, and international comparability. Also, there were limitations of the study because the latest input-output data was unavailable. The new data for 2015, which are expected to be published in 2017, will provide a deeper insight into the change of technology and the role of intermediary inputs. 


\section{REFERENCES}

Ahmadi-Esfahani, F. Z. (2006): Constant Market Shares Analysis: Uses, Limitations and Prospects. Australian Journal of Agricultural and resource Economics, 50(4): 510-526.

Balassa, B. (1965): Trade Liberalization and Revealed Comparative Advantage. Manchester School of Economic and Social Studies Journal, 33(2): 99-123.

Baldwin, E. R. (1958): The Commodity Composition of Trade: Selected Industrial Countries, 1900-1954. Review of Economics and Statistics, 40(1): 50-68.

Balla, E. (2014): Sectoral Interdependencies and Key Sectors in the Romanian, Hungarian and Slovak Economy - An Approach Based on Input-Output Analysis. Acta Universitatis Sapientiae, Economics and Business, 2: 37-57.

Belová, A. - Smutka, L. - Rosochatecká, E. - Bazina, A. (2012): Competitiveness of Domestic Production of Poultry Meat on the EU Market and on the World Market. In: Agric On-Line Papers in Economics and Informatics. Czech University of Life Sciences, Faculty of Economics and Management, Prague, Czech Republic.

Berezvai, Zs. (2015): The Pricing Strategies of Hungarian Food Retail Chains during the Last Recession. Acta Oeconomica, 65(3): 393-411.

Bojnec, Š. - Fertö, I. (2007): Trade Advantages and Integration of Croatian, Hungarian and Slovenian Agro-Food Trade with the European Union. Periodica Polytechnica, Social and Management Sciences, 15(1): 3-10.

Bojnec, Š. - Fertő, I. (2009): Agro-Food Trade Competitiveness of Central European and Balkan Countries. Food Policy, 34(5): 417-425.

Bojnec, Š. - Fertő, I. (2010a): Structure and Convergence of Agro-Food Trade of Central and Eastern European Countries with the European Union during Pre-Accession. Ekonomický ćasopis, 58(7): 677-689.

Bojnec, Š. - Fertő, I. (2010b): South-Eastern European Agro-Food Trade Specialization. Eastern European Economics, 48(3): 22-51.

Bojnec, Š. - Fertő, I. (2014): Agri-Food Exports from European Union Member States Using Constant Market Share Analysis. Studies in Agricultural Economics, 116(2): 82-86.

Bojnec, Š. - Fertö, I. (2015): Agri-Food Export Competitiveness in European Union Countries. Journal of Common Market Studies, 53(3): 476-492.

Buturac, G. (2013): Beyond the Global Recession: Mutual Trade and Economic Convergence. Ekonomski pregled, 64(4): 303-326.

Buturac, G. - Lovrinčević, Ž. - Mikulić, D. (2014): Export Competitiveness of Croatian Textile Industry - CMS Analysis and Importance for Economy. Tekstil ve konfeksiyon, 24(2): 158-168.

Carraresi, L. - Banterle, A. (2015): The Agri-Food Competitive Performance in the EU Countries: A Fifteen Years Retrospective. International Food and Agribusiness Management Review, 18(2): 37-62.

D’Hernoncourt, J. - Cordier, M. - Hadley, D. (2011): Input-Output Multipliers Specification Sheet and Supporting Material. Spicoza Project Report, Université Libre de Bruxelles - CEESE.

Fagerberg, J. - Sollie, G. (1987): The Method of Constant Market Shares Analysis Reconsidered. Applied Economics, 19(12): 1571-1583.

Ignjatijević, S. - Ćirić, M. - Carić, M. (2013): International Trade Structure of Countries from the Danube Region: Comparative Advantage Analysis of Export. Ekonomcky Časopis, 61(3): 251-269.

Ignjatijević, S. - Milojević, I. - Cvijanović, G. - Jandrić, M. (2015): Balance of Comparative Advantages in the Processed Food Sector of the Danube Countries. Sustainability, 7(6): 69766993. 
Jempa, C. J. (1986): Extensions and Application Possibilities of the Constant-Market-Shares Analysis. Groningen: Rijkusuniversiteit.

Kapur, S. N. (1991): The Structure and Competitiveness of India's Exports. Indian Economic Review, 26(2): 221-237.

Krueger, A. (1980): Trade Policy as an Input to Development. American Economic Review, 70(2): 288-292.

Leamer, E. E. - Stern, R. (1970): Quantitative International Economics. Boston: Allen \& Bacon.

Leontief, W. (1986): Input-Output Economics. New York: Oxford University Press.

Lovrinčević, Ž. - Buturac, G. - Mikulić, D. (2015): Export Performance of the Croatian Wood Industry and Its Contribution to the Overall Croatian Economy. Forest Products Journal, 65(3-4): $159-165$.

Majkovič, D. - Bojnec, Š. - Turk, J. (2007): Development of New Members' EU Trade: Evidence from the Slovenian Agri-Food sector. Post-Communist Economies, 19(2): 209-223.

Merkies, A. H. Q. M. - van der Meer, T. (1988): A Theoretical Foundation for CMS Analysis. Empirical Economics, 13(2): 65-80.

Milana, C. (1988): Constant-Market-Shares Analysis and Index Number Theory. European Journal of Political Economy, 4(4): 453-478.

Miller, E. R. - Blair, D. P. (2009): Input-Output Analysis: Foundations and Extensions. $2^{\text {nd }}$ ed., Cambridge: Cambridge University Press.

Procházka, P. - Smutka, L. (2012): Czech Republic as an Important Producer of Poppy Seed. In: Agris On-Line Papers in Economics and Informatics. Czech University of Life Sciences, Faculty of Economics and Management, Prague, Czech Republic.

Qineti, A. - Rajcaniova, M. - Matejkova, E. (2009): The Competitiveness and Comparative Advantage of the Slovak and the EU Agri-Food Trade with Russia and Ukraine. Agricultural Economics, 55(8): 375-383.

Richardson, J. D. (1971): Constant-Market-Shares Analysis of Export Growth. Journal of International Economics, 1(2): 227-239.

Rusali, A. M. (2013): Evaluation of the Romanian Agricultural Products Specialization in the IntraSectoral Foreign Trade. Agricultural Economics - Czech, 10(1): 77-83.

Soklis, G. (2009): The Conversion of the Supply and Use Tables to Symmetric Input-Output Tables: A Critical Review. Bulletin of Political Economy, 3(1): 51-70.

Šidlauskaitè, B. - Miškinis, A. (2013): The Development of Economic Structure and Inter-Industry Linkages in the Baltic Countries. Ekonomika, 92(2): 32-48.

Ten Raa, T. (2005): The Economics of Input-Output Analysis. Cambridge: Cambridge University Press.

Török, A. - Jámbor, A. (2013): Agri-Food Trade of the New Member States since the EU Accession. Agricultural Economics - Czech, 59(3): 101-112.

Tyszynski, H. (1951): World Trade in Manufactured Commodities. The Manchester School of Economic and Social Studies, 19(3): 272-304.

Vološin, J. - Smutka, L. - Selby, S. (2011): Analysis of External and Internal Influences on CR Agrarian Foreign Trade. Agricultural Economics - Czech, 57(9): 422-435. 